This document is the accepted manuscript version of the following article:

waltert, F., \& Schläpfer, F. (2010). Landscape amenities and local development: a review of migration, regional economic and hedonic pricing studies. Ecological

Economics, $70(2)$, 141-152. https://doi.org/10.1016/j.ecolecon.2010.09.031

\title{
Landscape amenities and local development: A review of migration, regional economic and hedonic pricing studies
}

\author{
Fabian Waltert $^{\mathrm{a}, \mathrm{b}, *}$ and Felix Schläpfer ${ }^{\mathrm{c}, \mathrm{d}}$
}

\author{
${ }^{a}$ Research Unit Economics and Social Sciences, Swiss Federal Institute for Forest, Snow \\ and Landscape Research, Birmensdorf, Switzerland \\ ${ }^{\mathrm{b}}$ Institute of Environmental Sciences, University of Zurich, Switzerland \\ ${ }^{\mathrm{c}}$ Institute for Environmental Decisions, Swiss Federal Institute of Technology ETH, Zurich, \\ Switzerland \\ d Socioeconomic Institute, University of Zurich, Switzerland
}

\begin{abstract}
With rapid urban expansion and loss of open space, attractive local landscapes will continue to gain importance in location decisions and on political agendas. The present study reviews the evidence on the local economic role of landscape amenities from two major strands of empirical research, migration and regional economic models, and hedonic pricing models. Following common amenity definitions we identify 71 relevant peer-reviewed studies and systematically assess the reported effects of the landscape amenity variables. The migration and regional economic studies suggest that migrants are attracted by amenities nearly as often as by low taxes. Reported effects of amenities on income and employment are less consistent. The hedonic studies suggest that nature reserves and land-cover diversity have mostly, open space and forest often, and agricultural land rarely positive effects on housing prices. Studies at larger geographic scales and studies containing urban or suburban areas were more likely to identify significant amenity effects. Some limitations of the evidence may be overcome with better datasets and modeling approaches. However, in line with other recent work, the limitations also highlight the need for complementary information from the analysis of political preferences for land use management.
\end{abstract}

Keywords: landscape amenities, migration, local development, hedonic pricing, environmental valuation, regional economic modelling 


\section{Introduction}

Traditional regional economic and migration studies largely ignored the possible effects of location-specific environmental amenities on demographic and economic change. Starting in the 1970s, however, two fundamental changes in U.S. internal migration patterns occurred (Greenwood, 1985): first, net-migration flows turned from the Northeast to the amenity-rich southern and western states; and second, the population growth in non-metropolitan regions started to exceed that of metropolitan areas. ${ }^{1}$ Searching for explanations of these developments, an increased demand for location-specific amenities - resulting from scarcity of natural amenities caused by urbanization as well as generally rising real incomes - was identified as one of the possible causes (Deller et al., 2001; Greenwood, 1985). Since that time, economists and regional scientists have shown an increasing interest in the role of environmental amenities in local and regional development. New modeling approaches such as regional growth models in a system-of-equations framework allowed them to explore the links between amenities, population, and economic development.

If amenities are at least partly capitalized in housing prices, their role for local development will be underestimated in regional economic and migration models (McGranahan, 2008). Hence, hedonic pricing models constitute an important complementary source of information on the role of environmental amenities. Although traditionally a separate literature, hedonic pricing studies that account for amenities can thus provide important additional insights on amenity-driven processes measured at the community and county level.

While early contributions in these fields used relatively limited amenity measures that included mainly climate amenity attributes or disamenities such as air and water pollution, it was in the 1990s when empirical researchers began to explore the role of a wider range of specific measures of natural and environmental amenities. Around that time, periurban amenities also gained increased interest in public policy as a factor that contributes to the quality of life and may be relevant to firm location decisions (e.g. Beyers and Lindahl,

\footnotetext{
${ }^{1}$ This pattern changed in the 1980 s when there was a revival of metropolitan net migration. However, in the 1990s net migration flows were in favor of rural areas again (see Fuguitt and Beale, 1996).
} 
1996; Cavailhès et al., 2004; Gottlieb, 1995; Johnson and Rasker, 1993). Governments started to shift agricultural support policies from producer support towards compensation for the provision of environmental amenities, and several researchers highlighted the management of natural amenities as a development tool for rural regions (e.g. Deller et al., 2001; Feinerman and Komen, 2003; Fuller et al., 2005; Green, 2001). Moreover, environmental amenities are increasingly seen as important determinants of urban and rural spatial development structures and phenomena such as urban sprawl and leapfrog development (e.g. Wu, 2006; Wu and Gopinath, 2008).

We provide a survey of the growing literature on the role of landscape amenities in regional and local demographic and economic change for the following reasons: (1) while single landscape amenity studies provide evidence for amenity impacts in the study regions it often remains unsure weather the results can be generalized and transferred to other regions. Hence, a synthesis of evidence can contribute to a better general understanding of amenity-driven processes. (2) With growing political awareness of the importance of landscape as a locational factor contributing to quality of life there is a need for scientific assessments on which to base land management and financing policies. (3) A synthesis of the current evidence helps to identify the state of the art of research as well as research needs towards better land use related policies.

Following common amenity definitions (e.g. Deller et al., 2001; Gottlieb, 1995; Green, 2001; Marcouiller and Clendenning, 2005) we define natural landscape amenities as landscape features that are location-specific, latent non-market input goods of an economy that directly enter a resident's utility function or attract firms in amenity-related industries. ${ }^{2}$ We seek answers to two main questions. (1) Do landscape amenities promote population growth and economic development, and what is the importance of amenities relative to other economic factors? We analyze the available empirical literature using migration models and models of regional growth to provide an overview of evidence on the links between landscape amenities, population growth, and economic indicators (25 studies). (2) Which landscape amenity attributes are capitalized in housing prices? To answer this second question, we compile and analyze evidence from the hedonic pricing literature on landscape amenities (46 studies). Based on the results, we discuss main insights but also remark on limitations of the literature as a basis for public decisions.

\footnotetext{
${ }^{2}$ The detailed selection criteria for the landscape amenity studies reviewed in section 4 and 5 are described in section 3 .
} 
The remainder of this article is composed of six sections. In the following section, we review the migration, regional economic, and hedonic pricing model approaches that form the theoretical basis of the compiled landscape amenity studies. The next section contains the definitions and selection criteria we use to analyze the existing empirical literature. In the forth and fifth section we then review the evidence from the compiled literature: models linking landscape amenities to demographic and economic development, as well as hedonic pricing studies. The two final sections present a discussion and conclusion.

\section{Models of amenity effects}

\subsection{Amenities and migration: Equilibrium and disequilibrium view}

Traditional micro theory views migration as a reaction to spatial disequilibria. People migrate in order to reach higher utility. They react to regional differences in economic opportunities, for example by migrating from low- to high-wage regions. Hence, in the disequilibrium view, migration is mainly a function of labor market variables. Since regional differentials are assumed to be associated with spatial disequilibrium, such differences in wages, rents or employment are sometimes referred to as noncompensating differentials (Hunt, 1993). Noncompensating differentials thus encourage migration as an equilibrating mechanism. An extensive body of literature on disequilibrium models has been built up since the early $20^{\text {th }}$ century. Surveys are provided by Greenwood (1985) and Hunt (1993). Amenities play virtually no role in traditional disequilibrium models.

In the late 1970s, an alternative model approach evolved, which has its roots in urban economics. In contrast to disequilibrium models, the equilibrium models allow for spatial differences in economic opportunities even in a spatial equilibrium. One of the first advocates of the equilibrium view was Graves, who explains the underlying rationale as follows (Graves, 1980, p. 227): "In this view of migration, market rents and wages are expected to adjust so as to leave utility constant over space. Hence, within a city rent differentials will emerge to remove any advantages associated with access to the center, parks and the like, while across cities wages will be lower in desirable areas by an amount equivalent in utility to the amenities obtained by locating there. Migration, viewed in this way, takes place as a result of changes in demand for location-fixed amenities". Spatial differences in wages or economic opportunities are viewed as compensation for different 
amenity endowments. Hence, such differences are commonly referred to as compensating differentials, since they are of purely compensating nature and do not induce migration (Greenwood et al., 1991). The crucial explanatory variables in equilibrium migration models are amenity variables and factors that may lead to changes in demand and supply of amenities. These factors include growing real incomes (see Graves and Linneman, 1979) combined with the generally assumed high income elasticity of demand for amenities (e.g. Marcouiller and Clendenning, 2005), as well as changing relative prices, which lead the system to a new equilibrium. Such adjustment processes are believed to occur relatively quickly, unlike those associated with the disequilibrium approach, where the tendency towards equilibrium is assumed weaker and the migration process and factor markets are viewed as less efficient (Hunt, 1993). Knapp and Graves (1989) provide an extensive review of equilibrium models.

Whether equilibrium or disequilibrium models are more appropriate for modeling migration is at least partly an empirical issue. Hunt (1993) analyzes the empirical literature related to this question. He finds evidence in favor of both approaches. Both the amenity consumption and the job search motive seem to determine migration, while the relative importance of the two motives remains unclear. However, it is important to note that most early studies and some of the newer studies use relatively narrow amenity measures containing only few amenity types such as climate or water variables, or disamenities such as air pollution and crime (e.g. Clark and Murphy, 1996; Mueser and Graves, 1995). Since the econometric evidence supports the idea that amenities are capitalized in wages and rents and that migration is partly amenity driven, Hunt (1993) concludes that pure disequilibrium models are misspecified. On the other hand, in most studies, economic opportunity variables are found to be significant migration determinants, which implies spatial disequilibrium and inefficient markets.

\subsection{Regional economic models of amenity effects on population, employment and income}

Natural amenities receive a growing attention not only in migration economics but also in the literature on regional growth and change. This literature explores the impact of locationspecific amenities both on population and on the local or regional economy as a whole. The literature suggests that there are several direct ways through which amenities can affect local and regional development. (1) Amenities may attract in-migrants with footloose incomes (e.g. Booth, 1999; Clark and Hunter, 1992; Poudyal et al., 2008). (2) Amenities may attract 
in-migrants who reveal their willingness to pay by accepting lower wages or higher rents (e.g. Judson et al., 1999; Roback, 1982, 1988). (3) Amenities may attract entrepreneurs who show their willingness to pay by accepting lower profits (e.g. Beyers and Lindahl, 1996; Johnson and Rasker, 1993). (4) Amenities may provide a basis for recreational and outdoor industries (e.g. Deller et al., 2001; Vanslembrouck et al., 2005). (5) Amenities may provide ecosystem services which directly enter individuals' utility functions or affect profits (e.g. Pimentel et al., 1995). In addition to those direct effects, amenity-induced population or job growth again may have indirect effects, for example by attracting skilled labor which in turn attracts firms (e.g. Gottlieb, 1995).

To model the impact of amenity and other exogenous variables on multiple dependent variables such as population, employment and income change, as well as interactions of those dependent variables, system-of-equations models are often employed. Models of this type have traditionally been used to explore empirically whether people follow jobs or jobs follow people (e.g. Steinnes and Fisher, 1974).

Carlino and Mills (1987) apply Steinnes and Fisher's intraurban system-of-equations model to an interregional context in order to explore the determinants of county growth in the U.S. This model has the following underlying assumptions on household and firm behavior: Households and producers are geographically mobile and choose their location in order to maximize their utility or profits, respectively. Consumer utility is derived from goods and services as well as from non-market, location-specific amenities. Firms maximize their profits by optimizing production costs and choice of a regional market. The result is an adjustment process in which "firms enter and leave regions until profits are equalized among regions at competitive levels, and households migrate until utility levels are equalized at alternative locations" (Carlino and Mills, 1987, p. 40). ${ }^{3}$ Hence, such regional adjustment models compromise between the equilibrium and the disequilibrium view (see section 2.1). The theoretical existence of a spatial equilibrium is acknowledged. However it is assumed that the system is constantly in disequilibrium, e.g. through continual exogenous shocks (Carruthers and Mulligan, 2007, p. 81-83).

Early contributions to this line of research used regional dummies as proxies for location-specific amenities (e.g. Carlino and Mills, 1987) or climate variables and costal dummies (e.g. Clark and Murphy, 1996). In the 1990s researchers started to include specific

\footnotetext{
${ }^{3}$ A detailed microeconomic derivation of the system of equations and its underlying assumptions is provided by Steinnes and Fisher (1974).
} 
land use types such as open space or forest land as amenity variables. Such extension may be essential for the empirical validity of the Carlino-Mills approach, as stressed by Graves and Mueser (1993, p. 78): The Carlino-Mills model "assumes that measured variables fully determine the ultimate equilibrium population. If there are any unmeasured stable differences between locations [...], this imparts a systematic bias that will reduce the apparent speed of movement toward equilibrium." Graves and Mueser explicitly note natural amenities and land rents as essential and often wrongly omitted variables. Among the most influential applications of Carlino and Mills' framework is the study by Deller et al. (2001) who add an equation for per capita income and use a variety of natural and non-natural amenity measures. Depending on whether the focus is solely on the direct amenity effects or also on the interplay of the endogenous variables, these studies estimate reduced forms of the model (e.g. Deller et al. 2001) or use simultaneous equations estimation methods such as two-stage least squares (e.g. Duffy-Deno, 1998) or the three-stage least squares technique (e.g. Lewis et al., 2003)to estimate the structural coefficients. ${ }^{4}$

An influential methodical advance was the development of spatial econometric techniques which were first applied to a regional growth model by Boarnet (1994) and subsequently used in studies on effects of amenities on regional change (e.g. Kim et al., 2005; Nzaku and Bukenya, 2005) or net migration (e.g. Ferguson et al., 2007; Rupasingha and Goetz, 2004). Recently, Partridge et al. (2008) used a geographically weighted regression (GWR) approach to study the impact of (non-landscape) amenities and other variables on employment growth in U.S. nonmetropolitan counties with focus on spatial heterogeneity.

\subsection{Amenities, rents, and wages: Hedonic pricing models}

Alongside the migration and regional economic models introduced above, hedonic pricing (HP) models are a further model type which contributes to the understanding of the role of amenities in economic change. The analysis of migration reflects the role of amenities on local economic change only partially when effects on property prices and wages are not considered. Furthermore, HP models allow comparing the implicit values of different amenity types by exploring preferences from property price data. The HP approach, whose theoretical framework was established by Rosen (1974), derives price equations from

\footnotetext{
${ }^{4}$ An up-to-date description of specification and interpretation issues in regional economic system-of-equations models is provided in Carruthers and Vias (2005).
} 
property sales data by regression and thereby allows valuation of different exogenous attributes of the property itself and its vicinity. Underlying this method is the equilibrium view introduced in section 2.1. Given mobile workers and mobile firms in a spatial equilibrium, spatial differences in land prices and wages compensate for differentials in the amenity endowment (Roback, 1982). Freeman (1979) provides a survey of HP theory and early HP studies. The hedonic price function typically describes the property price as a function of three categories of independent variables: structural, neighborhood, and environmental attributes. One subcategory of environmental variables is amenities. The first step in an HP study is to calculate the implicit price of the attributes of interest by hedonic regression. Using this information and data for observed quantities and income, inverse demand and marginal willingness to pay functions can be estimated in a second step (Freeman, 1979). In most amenity HP studies, this second step is omitted. Exceptions are e.g. Day et al. (2007), Garrod and Willis (1992), Mahan et al. (2000) and Poudyal et al. (2009).

Contrary to migration and regional economic approaches, the HP method can reveal preferences for specific amenity types at small spatial scales. Hence, also effects of accessibility, distance or visibility of amenity features can be captured. This high spatial resolution usually comes at the cost of limited spatial coverage meaning that HP studies often cover only one neighborhood, community, or county.

The interpretation of hedonic property value studies has some limitations. As shown by Roback $(1982,1988)$ and subsequent empirical work, amenities may be capitalized not solely in property prices but also in wages. Consequently, single-market studies may underestimate amenity values (Graves and Knapp, 1985). ${ }^{5}$ Another issue is that the assumptions underlying the hedonic technique, in particular the assumption of equilibrium in the housing market, are criticized. Furthermore, there are some critical econometric issues. Estimation results are sensitive to the choice of the functional form, which cannot be purely theoretically determined (Rosen, 1974). A more recent issue concerns the consequences of spatial autocorrelation resulting from spatially correlated omitted variables or spatial externalities. Its neglect in HP or other spatial data can lead to inefficient estimates and biased standard errors (Leggett and Bockstael, 2000) and therefore may demand alternative

\footnotetext{
${ }^{5}$ Nevertheless, multi-market HP studies containing landscape amenity variables as defined in section 1 are rare. Of the studies reviewed in section 5 all but one (Hand et al., 2008) are single-market hedonic property value studies.
} 
specifications or the estimation of models which explicitly incorporate spatial effects, such as spatial lag or spatial error models (see e.g. Anselin, 1988, 2002; Anselin and Bera, 1998). Can (1992), Dubin (1992), and Holloway et al. (2007, pp.557-559) discuss spatial econometric issues specifically in HP models.

\section{Definitions and selection criteria}

In this section, we provide definitions and article selection criteria which we then apply in compiling and analyzing the empirical literature.

As outlined in the introduction, we focus on landscape features that are locationspecific, latent non-market input goods of an economy and directly enter a resident's utility function or attract firms in amenity-related industries. Landscape amenity attributes are demanded for their recreational and aesthetic utilities rather than as raw materials used in the production process. Examples of such attributes are agricultural land, forests, wildlife habitats, natural preserve areas, wetlands and open space. Other commonly analyzed amenity attributes, such as climate (e.g. Graves, 1980), air quality (e.g. Harrison and Rubinfeld, 1978), watercourses (e.g. Colwell and Dehring, 2005), and "non-natural" green space such as city parks (e.g. Tajima, 2003), are not the subject of our analysis, although they may likewise affect economic change. A further prerequisite is that natural landscape amenities must be identifiable and not part of a broader composite index that also contains, for example, non-environmental amenities.

All articles we analyzed use revealed preference models relating landscape amenities (see definition in section 1) to regional or local economic change in developed countries. The literature considered in this survey consists of three different model types: Migration models, regional economic models and HP models. The survey includes articles published in peer-reviewed journals between 1970 and 2009. We found most articles by searching the databases Web of Science and Econlit. ${ }^{6}$ We used several combinations of the following keywords: (1) resource keywords: landscape, open space, amenities, natural, federal land, preservation; (2) model keywords: carlino, hedonic; (3) other keywords: population, migration, employment, income, growth, wage. Using these queries we found several hundred articles of which 71 (25 regional economic and migration studies and 66 hedonic

\footnotetext{
${ }^{6}$ Additional literature was searched by consulting the references of relevant articles. Some of the HP studies were found in a review paper on open space valuation (McConnell and Walls, 2005).
} 
pricing studies) used landscape amenity variables consistent with our definition (see section 1) and fulfilled all criteria concerning model type, data origin, research question and source defined above. With the exception of seven HP studies and four recent regional economic and migration studies, all studies in our sample use U.S. data. ${ }^{7}$

\section{Empirical evidence from regional economic and migration models}

The regional economic and migration studies analyzed in this section are heterogeneous in several dimensions: by model type, amenity variables, dependent variables, geographical coverage and the estimation method employed. We analyzed the evidence in a semiquantitative review of reported effects. Specifically, we examine the frequencies of significant reported amenity impacts on population/migration, employment and income variables, and we compare these with the impacts of fiscal and economic opportunity variables.

\subsection{Study sample and amenity types}

Based on the criteria defined above, we found 25 articles with 60 reported estimates of amenity impacts on dependent variables of the three categories "demography", "employment" and "income" (see Appendix A). The articles were published between 1981 and 2009 in 17 academic journals mainly in the fields of regional, agricultural, and urban economics. Most studies used county-level data. Some researchers chose other spatial resolutions, namely municipalities (Ali et al., 2007; Ferguson et al., 2007; Gottlieb, 1995; Lundgren, 2009), Bureau of Economic Analysis Economic Areas (Greenwood and Hunt, 1989), State Economic Areas (Williams, 1981), Standard Metropolitan Statistical Area (SMSA) census units (Porell, 1982) and census tracts (Boarnet et al., 2005). The spatial coverage ranges from several states, counties or communities (e.g. Booth, 1999; DuffyDeno, 1997a, 1997b, 1998; Lewis et al., 2002, 2003; Lundgren, 2009) to the entire (or the entire rural) U.S. (e.g. Clark and Hunter, 1992; Deller et al., 2001; McGranahan, 2008),

\footnotetext{
${ }^{7}$ HP studies from outside the U.S. use data from Great Britain (Cheshire and Sheppard, 1995; Garrod and Willis, 1992), the Netherlands (Luttik, 2000), Finland (Tyrväinen, 1997; Tyrväinen and Miettinen, 2000), Australia (Tapsuwan et al., 2009), and South Korea (Lee and Linneman, 1998). Exceptions in the field of the U.S.-dominated migration and regional economic studies are papers from Canada (Ali et al., 2007; Ferguson et al., 2007), Great Britain (Park et al., 2009) and Sweden (Lundgren, 2009).
} 
Canada (Ali et al., 2007; Ferguson et al., 2007), and England (Park et al., 2009). The majority of the studies employ regional economic system-of-equations models. Three studies (Clark and Hunter, 1992; Ferguson et al., 2007; Porell, 1982) employ single-equation migration models with migration flows as the sole dependent variable. Nine articles used spatial econometric techniques $^{8}$ (see Appendix A).

The amenity measures in our sample are usually defined as proportions of a certain land-use category relative to the total land surface. Many studies use the proportion of land governed by state or federal agencies, such as the National Park Service (NPS) or the U.S. Forest Service (USFS) as their amenity variable (e.g. Duffy-Deno, 1997a, 1997b, 1998; Poudyal et al., 2008). Others use land-use categories such as wilderness land, conservation land, or forest land (e.g. Ali et al., 2007; Booth, 1999; Ferguson et al., 2007; Lundgren, 2009; McGranahan, 2008; McGranahan and Wojan, 2007; Nzaku and Bukenya, 2005; Park et al., 2009; Poudyal et al., 2008). Such measures are not uniformly defined and reported categories may overlap among studies. A third approach for the construction of amenity measures are amenity indices constructed by means of the principal component method (Deller and Lledo, 2007; Deller et al., 2001; Kim et al., 2005; Porell, 1982). A useful distinction of land amenities is not possible in those studies since aggregates rather than effects of individual amenity attributes are captured. The migration and regional economic studies that we analyzed thus do not allow us to answer questions regarding the effects of specific landscape amenity types.

\subsection{Reported amenity effects on demography, employment and income}

An overview of the landscape amenity effects on different demographic and economic variables is provided in table 1 . The dependent variables of the migration and regional economic studies analyzed here can be summarized in three categories: population and migration (occurring in 23 studies), employment (occurring in 17 studies) and income

\footnotetext{
${ }^{8}$ Lewis et al. $(2002,2003)$ and McGranahan (2008) control for spatial autocorrelation by constructing a spatial weight matrix and testing the null hypothesis of spatial independence using the spatial autocorrelation statistic Moran's I (see e.g. Anselin, 1988; Anselin and Bera, 1998). Ali et al. (2007), Boarnet et al. (2005), Ferguson et al. (2007), Gottlieb (1995), Kim et al. (2005) and Nzaku and Bukenya (2005) applied spatial econometric models such as spatial lag or error models, which explicitly incorporate spatial effects (see e.g. Anselin, 1988, 2002; Anselin and Bera, 1998).
} 
(occurring in 8 studies). Overall, of 60 estimated amenity effects ${ }^{9}$ on these dependent variables, 21 were positive and significant. 2 negative effects were found, and the remaining 38 coefficient estimates were non-significant. The highest proportion of positive and significant coefficient estimates was found for effects on variables of the category "population and migration" where 10 out of 26 coefficients were significant and positive while 2 coefficients were significant and negative. Evidence for amenity effects on income is scarce. There were only 11 reported income effects estimated in 8 different studies. 2 out of the 4 significant estimates were obtained for specific types of income (wages and transfers) rather than for total per capita income. Moreover, the significant estimates stem from only three studies (Booth, 1999; Deller and Lledo, 2007; Rasker, 2006). Therefore, it is not possible to make any general statements regarding the impact of landscape amenities on regional income based on empirical studies. Finally, the evidence suggesting an amenity impact on employment is limited. 7 out of 23 coefficient estimates were positive and significant; the remaining 16 estimates were insignificant. The conclusion that can be drawn from the 25 analyzed articles is that population growth and net migration tend to be higher in high-amenity regions. However, the effect on employment change is less well established, while the impact on income change remains unclear.

How important are these amenity effects compared with other drivers of economic change? For this comparison, we also report effects of the two most common lagged economic opportunity variables - (wage-)income and unemployment - and a fiscal variable - tax burden - in table $1^{10}$. In our study sample, high wages and incomes in the past did not induce a positive demographic and economic development. Only 5 out of the 33 estimated coefficients were positive, while 13 were even negative and significant. Also, low unemployment in the past did not explain future growth. However, 6 out of 12 estimates suggest that low local tax rates attracted people, while the effect on employment and income seems limited. Overall, these findings tend to support the equilibrium view (see section 2.1) since the evidence for disequilibrium forces is limited, while amenities seem to play a significant role and partly compensate lower wages (e.g. Nzaku and Bukenya, 2005).

\footnotetext{
${ }^{9}$ Since some of the amenity coefficients estimated stem from different equations of the same system-ofequations model, the 60 coefficients are not completely independent.

${ }^{10} \mathrm{We}$ compare the frequency of significant effects of amenity and economic variables rather than reporting elasticities for two reasons: (1) in 13 studies, no variable means are reported which makes it impossible to calculate elasticities at the sample mean. (2) Due to the substantial heterogeneity in dependent and independent variables a comparison of elasticities of amenities and economic variables is problematic (see section 4.1).
} 
However, these findings are not uniform; some studies found that economic opportunity variables explain migration better than amenity variables (e.g. Park et al., 2009). Greenwood and Hunt (1989, p. 2) argue that "if employment is growing most rapidly in amenity rich areas, and if employment change is not included as an explanatory variable in the migration equation, then the importance of job opportunities will in part be reflected in the coefficients associated with the amenities". In fact, only ten studies in our sample used employment growth as an independent variable in their population equations. Eight of them (Clark and Hunter, 1992; Deller and Lledo, 2007; Greenwood and Hunt, 1989 ${ }^{11}$; Lewis et al., 2002, 2003; McGranahan, 2008; McGranahan and Wojan, 2007; Williams, 1981) conclude that high employment growth significantly promoted population change or net-migration. In addition, Porell (1982, p. 156) finds that "whereas in long-run equilibrium attractive QOL [quality of life] should be compensated by less attractive economic incentives, several SMSA's [...] offered attractive economic incentives in addition to attractive QOL". Moreover, most of these studies did not control for housing prices, which might cause biases since amenities may capitalize not only in wages but also in rents (Roback, 1982, 1988). Hailu and Rosenberger (2004) and Poudyal et al. (2008) use median housing values in their model and found that low housing values were not positively associated with subsequent population growth.

Finally, it must be emphasized that the amenity effects reported in table 1 are direct or total effects. ${ }^{12}$ System-of-equations models estimated in their structural form allow partitioning of this effect in principle into a direct and an indirect effect (see e.g. DuffyDeno, 1997b, 1998; Lewis et al., 2002, 2003; McGranahan, 2008; McGranahan and Wojan, 2007). This approach yields a more distinct insight into the complex relationships between the endogenous variables. If reduced form estimates for example display significant amenity effects on job growth, structural form estimates provide additional information on whether the amenity effects are direct (e.g. by fostering amenity-based leisure industry) or indirect (by attracting skilled workers). A concrete example is given in the carefully conducted study by Lewis et al. (2002) who find that in the U.S. Northern Forest region the conservation land

\footnotetext{
${ }^{11}$ Greenwood and Hunt (1989) used workforce data. This may partly explain the high relative importance of job variables in their findings. Moreover, they only considered the direct effects of amenities and jobs on netmigration. However, they remark that amenity-rich places may attract migrants indirectly through job growth if amenities are capitalized into wages and lower wages attract firms.

${ }^{12}$ If both direct and total effects were calculated in a study, we report the direct effects in Appendix A and table 1.
} 
share had a positive direct effect on net migration, whereas net migration positively influenced employment at the end of period. Therefore, the amenity variable had a direct effect on net migration as well as an indirect effect on employment.

\subsection{Further findings}

Some of the 25 studies focus on the commonly expressed concern that fostering natural preserves and wilderness areas might crowd out resource-sector employment, such as employment in the manufacturing of wood products, and harm the economy through lowering total employment, or replacing jobs in the resource-based sector with low-wage service jobs. Duffy-Deno (1998) finds that two types of land-use restrictions, the ownership of land by the U.S. Forest Service (USFS) and the Bureau of Land Management (BLM), had a negative impact on resource employment while there was no evidence of such an effect for federal wilderness. Duffy-Deno (1997a) and Lewis et al. (2002) find no evidence for the crowding-out hypothesis. Moreover, Lewis et al. (2003) and Rasker (2006) could not reject the hypothesis that no negative wage / income effects result from preservation lands. Extensive evidence and a rationale against the crowding-out theory is provided in Power and Barrett (2001).

Another object of research is the determinants of an individual's demand for landscape amenities. Personal characteristics are an important migration determinant alongside with economic, fiscal and amenity conditions in the sending and receiving locations (Greenwood, 1985). Clark and Hunter (1992) analyze the relative importance of amenity, fiscal and economic opportunity variables in a life-cycle migration framework. They estimate a net-migration equation for five-year age cohort of white males. The landscape amenity variable in their model (share of land in state parks, forests, water-use areas, trails, and other recreational areas) is found to be a positive and significant determinant of net migration only for age cohorts from 40 upwards. The authors obtain similar results for all other natural amenities (climate and coastal variables): they find significant amenity effects for middle-aged and older males, while younger males tended to be attracted by labor-market features and migrate to city centers. The results of a recent retiree migration study using a particularly comprehensive set of landscape amenity variables (Poudyal et al., 2008) confirm the relatively high importance of landscape amenities for retiree's locational choice. In a further recent article, Ferguson et al. (2007) estimate a comparable model using data from Canadian communities and a broadly defined 
amenity group containing landscape, climate and nonnatural amenities. They conclude that in rural areas economic factors rather explain population growth than amenities do. However, the influence of amenities as locational factor is rising with the age of the migrants. In urban areas amenities and economic factors were of similar importance as migration determinants.

\section{Empirical evidence from hedonic property value models}

\subsection{Study sample and definition of amenity groups}

Based on the definitions and selection criteria introduced, we found 46 relevant articles with 53 independent hedonic regressions (see Appendix B). ${ }^{13}$ These articles were published between 1986 and 2009 in 26 academic journals mainly in the fields of environmental and resource, agricultural, and real-estate economics. In the present study sample, there are often several model specifications reported for individual independent regressions. Moreover, the reported models may contain one or several amenity coefficients, and the definition of the amenity variables is never exactly the same in any two studies. To assess the reported evidence we distinguish the characteristics "regression", "specification", "amenity group", and "amenity coefficient". Hence, the reported amenity coefficients can be written $\underline{b}_{\mathrm{ijkl}}$, where $\underline{\mathrm{i}}$ indicates the regression, $\mathrm{j}$ denotes the particular specification of the regression, $\underline{\mathrm{k}}$ is the amenity group and $\underline{1}$ indicates the individual reported amenity coefficient.

We distinguish six landscape amenity groups: open space ("open space"), forest, trees and wooded areas ("forest"), wilderness, conservation areas and preserved land ("preserve"), wetlands ("wetland"), land in agricultural use ("agriculture") and land cover diversity or richness (“diversity”). These amenity variables appear as explanatory variables in the hedonic property value models in addition to other exogenous variables such as property attributes, neighborhood, and socio-economic variables. Treating the amenities as exogenous and time invariant implies that changes in amenities are assumed to be small at the time scales relevant to hedonic price formation (see Riddel, 2001). The amenity measures occur as proximity variables (e.g. distance to nearest forested area), proportion measures (e.g. percentage of land classified as open space within a given distance from the

\footnotetext{
${ }^{13}$ Geoghegan et al. (2003), Nelson (1986), Nicholls and Crompton (2005), and Thorsnes (2002) estimated several models with independent sub-samples.
} 
property) or as binary variables (e.g. vicinity of preserved land). Most studies in the sample deal with forest and open space amenities solely or with a combination of different landscape amenity types.

\subsection{Reported amenity effects on property values}

As mentioned above, many hedonic property value studies employ several alternative definitions of an amenity (e.g. percentage of open space within a radius of 200 and within a radius of 500 meters from the property) or estimate different specifications using the same dataset. For a first quantitative assessment of the reported amenity effects we pool the reported coefficients for each amenity group $\underline{\mathrm{k}}$ and each specification $\mathrm{j}$ within regressions $\underline{\mathrm{i}}$, yielding a sample of $n=84$ observations for $\underline{b}_{i \underline{k}}$. We define $\underline{b}_{\underline{i}}$ as a significant reported amenity effect if at least $50 \%$ of the pooled amenity coefficients were positive and significant at the $5 \%$ level. In addition, we define $\underline{b}_{\underline{i k}}$ as robust if all pooled amenity coefficients were positive and significant. Table 2 reports the number of observations that were significant and robust, respectively, for each amenity group. The underlying sample is presented in Appendix B.

For each of the amenities "open space", "forest" and "wetland" the reported amenity effects were significant in about half of the observations. The highest proportion of significant amenity effects were found for "preserve" ( 9 out of 11 observations) and for "diversity" (6 out of 8 observations).

Of 9 observations for agricultural land-use ("agriculture") only 2 were positive and significant. The agricultural land-use variables in the regressions were cropland/farmland (Bockstael, 1996; Hardie et al., 2007; Irwin 2002; Johnston et al., 2001; Kuminoff, 2009; Ready and Abdalla, 2005), pasture (Bockstael, 1996) and unspecified agricultural land (Neumann et al., 2009; Paterson and Boyle, 2002; Smith et al. 2002). The variables were specified as percentage of a neighborhood area or within a certain radius around the property (Bockstael, 1996; Hardie et al., 2007; Irwin, 2002; Paterson and Boyle, 2002; Kuminoff, 2009), as zone or adjacency dummy (Johnston et al., 2001; Ready and Abdalla, 2005; Smith et al. 2002), or as a distance measure (Johnston et al.,. 2001; Neumann et al., 2009; Smith et al. 2002). A positive and significant impact on property prices was found for pastureland (Bockstael, 1996) and in one case - depending on the distance - for cropland (Kuminoff, 2009). The remaining HP studies found non-significant or even negatively significant relationships between cropland/agricultural land and property prices. Johnston et al. (2001) 
argue that amenity effects of agricultural open space may - depending on the type of farms partly be overcompensated by disamenity effects of agricultural production such as odors, water pollution and noise (see also Palmquist et al., 1997). In a carefully conducted study, Ready and Abdalla (2005) included a variable for animal facilities in order to reduce omitted variable bias in the coefficients of the agricultural land-use variables. Their results suggest that residents reveal a significant and positive willingness-to-pay for agricultural land within a radius of 400 to 1600 meters from the property, while the percentage of agricultural land within a radius of 400 meter was not significant.

While forests provide the basis for timber production, they may also provide amenity values in terms of recreational, ecological and aesthetic benefits. The coefficients for forest measures were quite variable. Studies finding nonsignificant or negative effects tended to use global measures of forest presence or distance or did not control for forest and forest management types (Benefield, 2009; Bockstael, 1996; Hardie et al., 2007; Irwin, 2002; Paterson and Boyle, 2002; Sander and Polasky, 2009; Smith et al., 2002; Tyrväinen, 1997; White and Leefers, 2007). Positive effects were found for urban forests (Luttik, 2000; Mansfield et al., 2005; Netusil, 2005; Poudyal et al., 2009; Tyrväinen and Miettinen, 2000) or forest preserves (Thorsnes, 2002). The strength and direction of forest effects on property prices seem to depend on the type of forest and forest management. A British HP study (Garrod and Willis, 1992) found that broadleaved woodland had a small but significantly positive impact on property prices, while production oriented conifers exhibited a significant negative influence. Kim and Johnson (2002) stand out by controlling for attributes related to industrial forest use such as clear-cut sites and even-aged management. Their findings suggest that recreational and aesthetic amenity values provided by forests can be offset by production oriented management. A particularly detailed study is also Cho et al. (2008) who examine how the amenity values of different forest types, patterns and edges vary according to the degree of urbanization. Moreover, in a very recent paper Poudyal et al. (2010) construct a sophisticated measure for forested landscape in a viewshed and find a positive impact of forest view on property prices.

The frequency of robust amenity effects was low, ranging from 0 out of 9 (for "agriculture") and 3 out of 20 (for "forest") to 4 out of 11 (for "preserve") and 4 out of 8 (for "diversity"). This confirms that the evidence in the literature is limited. To a certain extent this may truly reflect weak or absent effects. However, results also depend on modeling approaches, definitions and measurement of amenities. One important point here is the 
choice of the baseline land-use variable in regressions. The consequence of this choice for the estimated amenity effects is rarely addressed ${ }^{14}$, which sets limits to comparisons across studies.

Using the same sample of 84 observations and the same definition of a significant coefficient, we also analyzed the determinants of significant amenity effects in a binary regression framework (see e.g. Jeppesen et al., 2002, p. 26). The explanatory variables in the model are the year of publication, a set of dummy variables for the different amenity types (using open space as the reference), and dummy variables coding for: local (data from one county) vs. regional scale of the study; rural (not including urban or sub-urban parts) vs. non-rural study areas; whether other natural (non-landscape) amenities were included in the specification; and whether the authors had made efforts to control for spatial autocorrelation. Of the amenity dummies, only agriculture was weakly significant in the binary regression $(\underline{\beta}=-1.83 ; \underline{p}=0.07)$. Studies conducted at a local scale were less likely to report significant amenity effects than studies conducted at a regional scale $(\underline{\beta}=-1.65 ; \underline{p}=0.10)$ and the probability of significant amenity effects was lower in rural than in (sub-)urban areas $(\underline{\beta}=$ $-1.70 ; \underline{p}=0.09)$. The remaining study characteristics were non-significant. ${ }^{15}$

\section{Discussion}

A clear finding is that evidence strongly concentrates on the U.S. in the compiled literature. Due to different economic, social and cultural environments the role of amenities in other developed countries may be different from that in the U.S. For example, considering the sizable budget involved in European agri-environmental policies ${ }^{16}$, a better understanding of the role of European landscape amenities is an important objective to which empirical research can contribute.

\footnotetext{
${ }^{14}$ An exception is the article of Ready and Abdalla (2005) who use zoning and broad land-use categories in their HP regression and provide results for both industrial and residential baseline land-uses.

${ }^{15}$ The dataset and statistical output are available from the authors on request.

${ }^{16}$ The European Union support for rural development for the period of 2007 to 2013 amounts to 88 billion Euros (http://ec.europa.eu/budget/documents/multiannual_framework_en.htm, accessed 09/13/2007). Of the 126-billion-Euro European Union budget for 2007, 34\% are allocated to the management of natural resources (http://ec.europa.eu/budget/budget_detail/current_year_en.htm, accessed 09/13/2007).
} 
The available regional economic and migration studies suggest that amenity-rich regions tended to grow faster in terms of population than other areas. Significant and positive amenity effects were comparable in frequency with those of a low tax burden. Several studies suggest that the conservation of natural amenities for recreational uses did not harm the local economy through crowding out resource-based employment. However, the overall impact on economic development remains unclear as the evidence on the link between amenities and employment or income is largely inconsistent. The notion of landscape amenities as a development tool therefore still lacks unambiguous empirical support. We identify two specific research needs. There is a need for regional economic system-of-equations studies with a broad range of specific amenity measures. New spatial analysis tools have the potential to overcome important data limitations of many earlier studies. Furthermore, attention should be paid to life-cycle effects and the personal characteristics of migrants attracted by amenities (see e.g. Clark and Hunter, 1992; Ferguson et al., 2007; Poudyal et al., 2008). Key questions are: (1) which individuals are attracted by which amenities? and (2) what are the consequences of the socioeconomic characteristics of these individuals with regard to the regional economic development? Approaches relying on household-level panel data and survey-based evidence could provide answers (e.g. Huffman and Feridhanusetyawan, 2007).

The evidence from hedonic pricing studies complements the insights from regional economic and migration models. Our analysis suggests that nature reserves and land cover diversity mostly and open space and forest frequently increase the prices of neighboring properties. By contrast, evidence of positive valuations of agricultural land by neighboring residents is scarce, perhaps because most studies fail to control for the type of agricultural production, while disamenities from intensive production might offset potential landscape amenity effects (Bergstrom and Ready, 2009). Moreover, positive amenity effects are more frequent in urban or suburban than in rural areas where landscape amenities tend to be less scarce. The limited consistency of results across hedonic pricing studies parallels the conclusions in reviews on hedonic values of air quality (Chay and Greenstone, 2005) and light-rail access (Redfearn, 2009) and may reflect a diversity of amenity definitions and model specifications (see 5.1). Nevertheless, the results show that landscape amenities are partly capitalized in rents. However, utility gains through higher amenity endowments may also be reflected in wages (Roback, 1982, 1988), which calls for multi-market hedonic models (e.g. Hand et al. 2008). A better understanding of this capitalization process may also 
help to better understand the relationship between amenities and employment, since the latter depends on wage levels.

A further source of evidence on how landscape amenities affect location decisions and hence local economic change is surveys. Economic survey research has focused on the monetary valuation of land use alternatives for use in cost benefit analysis. Unfortunately, due to uncertainties of the survey process, that evidence remains inconclusive in many ways (Bergstrom and Ready, 2009). Furthermore, the focus on average or total willingness to pay in that literature is also somewhat disconnected from the needs of stakeholders and policymakers in land use planning (Banzhaf, 2010, p. 600). However, a plethora of other survey interview, focus groups and workshop approaches has contributed to the understanding of people's landscape needs and preferences (Matsuoka and Kaplan, 2008) regarding both public land use decisions (e.g. Banzhaf, 2010; Kline and Wichelns, 1996) and private location decisions (e.g. Milburn et al., 2010).

For instance, a large mail survey in three rapidly growing Michigan counties finds that natural and openness features were important for only a minority of home buyers (Vogt and Marans, 2004). Importance was higher for of higher income and older individuals and for those living in rural townships. In contrast, the same features items ranked at the top in a series of focus groups of residents in neighborhoods with much open space. In political decisions, peoples' reasons and preferences for protection appear to depend on the reference land use: for instance, in the case of non-agricultural land, ecological and environmental values rank at the top, while "agrarian" motives score higher in protecting farmland (see Banzhaf, 2010, p. 594). These distinctions and variations in preferences between settings, neighborhoods and segments of the population, which are difficult to identify in standard hedonic pricing and regional economic models, are of potential interest to policy makers. We suggest that the value of the economic modeling approaches reviewed in this paper could be increased by survey evidence on the underlying decision processes in the same locations. Evidence about local decision motives would at the same time facilitate judgments about the possibility to transfer study results across regions.

Finally, the results by Vogt and Marans (2004) also point to another issue on which the reviewed evidence is somewhat limited - the fact that the land-based amenities are not necessarily exogenous. The authors find that natural and openness features were rated more highly by homeowners who preferred large lot, auto-oriented neighborhoods, highlighting how homeowner are attracted by and degrade amenities at urban fringes (Chen et al., 2009). 
Further potential side effects of amenity-induced growth (e.g. retiree-attraction policies) include congestion, pollution, rising housing prices, and cost of living for the locals (Reeder, 1998; Skelley, 2004). These authors propose strategies in order to use natural amenities as development tool for rural regions while minimizing such side effects. However, more attention should be paid to landscape and land use sustainability. Conversely, environmental policies to preserve amenities may be endogenous as well (Fleming et al., 2009, p. 3), which is perhaps most evident from the relative success of open space referenda in density populated regions. The dynamic interactions of landscape amenities, development and environmental policy are beyond the scope of the reviewed empirical approaches. They remain an important topic for further study using approaches that take political responses to amenity changes into account (Chen et al., 2009; Nelson et al., 2007; Walsh, 2007).

\section{Conclusion}

Empirical work on effects of amenities on property prices, population, employment, and income is useful to understand the increasingly important links between landscape management and economic change. While several studies have surveyed the role of environmental regulations on economic development (e.g. Jeppesen et al., 2002), the present study is the first to provide a synopsis of the available evidence on the role of land-use related amenities in local economic change. ${ }^{17}$

We conclude that, in spite of considerable efforts that went into the reviewed empirical research, the evidence on any positive role of landscape amenities for local economic development, or even merely on housing prices, remains limited. On its own, the evidence would hardly suffice as an argument for substantial public spending on landscape amenities. However, this perception contrasts sharply with the evidence from hundreds of voting decisions on open space preservation across the U.S. which show that the citizens are willing to authorize billions of tax dollars for the conservation of landscape amenities (e.g. Kline and Wichelns 1994, Kotchen and Powers 2006, Nelson et al. 2007). The apparent paradox reminds us that the evidence obtained from the analysis of market processes (including location decisions) reflects only one (possibly minor) part of the value of land use related externalities. The environmental economic and regional science literature has placed

\footnotetext{
${ }^{17}$ In a recent working paper Fleming et al. (2009) collected and analyzed evidence on amenity impacts on rural development. In contrast to the present study they focus on natural rather than just landscape amenities and their compilation is limited to 17 articles published between 2001 and 2008.
} 
much emphasis on market decisions and relatively little emphasis on the analysis of political decisions. In order to provide useful advice to policy makers, regional and environmental economists' attention should shift towards a fuller consideration and analysis of political preferences and institutions for land use management. This conclusion parallels findings by Hellerstein et al. (2002) and in the recent report on the valuation of ecosystems and ecosystem services (USEPA 2009) which also emphasizes the role of political deliberation and decision processes. With the traditional emphasis on market behavior, we are missing important information that is relevant for land use decisions at local to national scales.

\section{Acknowledgements}

The authors thank Steven C. Deller, Peter Zweifel and various participants at the 2009 Annual Meeting of the European Association of Environmental and Resource Economists for valuable comments on an earlier version of the manuscript. We are grateful to the Swiss National Science Foundation for funding (Grant 100012-105841 to Felix Schläpfer). 


\section{References}

Acharya, G., Bennett, L.L., 2001. Valuing open space and land-use patterns in urban watersheds. Journal of Real Estate Finance and Economics 22 (2-3), 221-237.

Ali, K., Partridge, M.D., Olfert, M.R., 2007. Can geographically weighted regressions improve regional analysis and policy making? International Regional Science Review 30 (3), 300-329.

Anderson, S.T., West, S.E., 2006. Open space, residential property values, and spatial context. Regional Science and Urban Economics 36 (6), 773-789.

Anselin, L., 1988. Spatial econometrics: Methods and models. Kluwer Academic Publishers, Dordrecht (NL).

Anselin, L., 2002. Under the hood issues in the specification and interpretation of spatial regression models. Agricultural Economics 27 (3), 247-267.

Anselin, L., Bera, A.K., 1998. Spatial dependence in linear regression models with an introduction to spatial econometrics, in: Ullah, A., Giles, D.E.A. (Eds.), Handbook of applied economic statistics. Marcel Dekker, New York, pp. 237-289.

Asabere, P.K., Huffman, F.E., 2009. The relative impacts of trails and greenbelts on home price. Journal of Real Estate Finance and Economics 38 (4), 408-419.

Banzhaf, H.S., 2010. Economics at the fringe: Non-market valuation studies and their role in land use plans in the United States. Journal of Environmental Management 91 (3), 592602.

Bastian, C.T., McLeod, D.M., Germino, M.J., Reiners, W.A., Blasko, B.J., 2002. Environmental amenities and agricultural land values: A hedonic model using geographic information systems data. Ecological Economics 40 (3), 337-349.

Benefield, J.D., 2009. Neighborhood amenity packages, property price, and marketing time. Property Management 27 (5), 348-370.

Bergstrom, J.C., Ready, R.C., 2009. What have we learned from over 20 years of farmland amenity valuation research in North America? Review of Agricultural Economics 31 (1), 21-49.

Beyers, W.B., Lindahl, D.P., 1996. Lone eagles and high fliers in rural producer services. Rural Development Perspectives 11 (3), 2-10.

Boarnet, M.G., 1994. An empirical model of intrametropolitan population and employment growth. Papers in Regional Science 73 (2), 135-152. 
Boarnet, M.G., Chalermpong, S., Geho, E., 2005. Specification issues in models of population and employment growth. Papers in Regional Science 84 (1), 21-46.

Bockstael, N.E., 1996. Modeling economics and ecology: The importance of a spatial perspective. American Journal of Agricultural Economics 78 (5), 1168-1180.

Bohlen, C., Lewis, L.Y., 2009. Examining the economic impacts of hydropower dams on property values using GIS. Journal of Environmental Management 90 (SUPPL. 3).

Booth, D.E., 1999. Spatial patterns in the economic development of the Mountain West. Growth and Change 30 (3), 384-405.

Can, A., 1992. Specification and estimation of hedonic housing price models. Regional Science and Urban Economics 22 (3), 453-474.

Carlino, G.A., Mills, E.S., 1987. The determinants of county growth. Journal of Regional Science 27 (1), 39-54.

Carruthers, J.I., Mulligan, G.F., 2007. Land absorption in U.S. metropolitan areas: Estimates and projections from regional adjustment models. Geographical Analysis 39 (1), 78-104.

Carruthers, J.I., Vias, A.C., 2005. Urban, suburban, and exurban sprawl in the rocky mountain west: Evidence from regional adjustment models. Journal of Regional Science 45 (1), 21-48.

Cavailhes, J., Peeters, D., Sekeris, E., Thisse, J.F., 2004. The periurban city: Why to live between the suburbs and the countryside. Regional Science and Urban Economics 34 (6), 681-703.

Chay, K.Y., Greenstone, M., 2005. Does air quality matter? Evidence from the housing market. Journal of Political Economy 113 (2), 376-424.

Chen, Y., Irwin, E.G., Jayaprakash, C., 2009. Dynamic modeling of environmental amenitydriven migration with ecological feedbacks. Ecological Economics 68 (10), 2498-2510.

Cheshire, P., Sheppard, S., 1995. On the price of land and the value of amenities. Economica 62, 247-267.

Cho, S.H., Bowker, J.M., Park, W.M., 2006. Measuring the contribution of water and green space amenities to housing values: An application and comparison of spatially weighted hedonic models. Journal of Agricultural and Resource Economics 31 (3), 485-507.

Cho, S.H., Kim, S.G., Roberts, R.K., Jung, S., 2009. Amenity values of spatial configurations of forest landscapes over space and time in the Southern Appalachian Highlands. Ecological Economics 68 (10), 2646-2657. 
Cho, S.H., Poudyal, N.C., Roberts, R.K., 2008. Spatial analysis of the amenity value of green open space. Ecological Economics 66 (2-3), 403-416.

Clark, D.E., Hunter, W.J., 1992. The impact of economic opportunity, amenities and fiscal factors on age-specific migration rates. Journal of Regional Science 32 (3), 349-365.

Clark, D.E., Murphy, C.A., 1996. Countywide employment and population growth: An analysis of the 1980s. Journal of Regional Science 36 (2), 235-256.

Colwell, P.F., Dehring, C.A., 2005. The pricing of lake lots. Journal of Real Estate Finance and Economics 30 (3), 267-283.

Day, B., Bateman, I., Lake, I., 2007. Beyond implicit prices: recovering theoretically consistent and transferable values for noise avoidance from a hedonic property price model. Environmental and Resource Economics 37 (1), 211-232.

Deller, S., Lledo, V., 2007. Amenities and rural Appalachia economic growth. Agricultural and Resource Economics Review 36 (1), 107-132.

Deller, S.C., Tsai, T.H.S., Marcouiller, D.W., English, D.B.K., 2001. The role of amenities and quality of life in rural economic growth. American Journal of Agricultural Economics 83 (2), 352-365.

Doss, C.R., Taff, S.J., 1996. The influence of wetland type and wetland proximity on residential property values. Journal of Agricultural and Resource Economics 21 (1), 120129.

Dubin, R.A., 1992. Spatial autocorrelation and neighborhood quality. Regional Science and Urban Economics 22 (3), 433-452.

Duffy-Deno, K.T., 1997a. Economic effect of endangered species preservation in the Nonmetropolitan West. Growth and Change 28 (3), 263-288.

Duffy-Deno, K.T., 1997b. The effect of state parks on the county economies of the West. Journal of Leisure Research 29 (2), 201-224.

Duffy-Deno, K.T., 1998. The effect of federal wilderness on county growth in the intermountain western United States. Journal of Regional Science 38 (1), 109-136.

Feinerman, E., Komen, M.H.C., 2003. Agri-environmental instruments for an integrated rural policy: An economic analysis. Journal of Agricultural Economics 54 (1), 1-20.

Ferguson, M., Ali, K., Olfert, M.R., Partridge, M., 2007. Voting with their feet: Jobs versus amenities. Growth and Change 38 (1), 77-110.

Fisher, L.M., Pollakowski, H.O., Zabel, J., 2009. Amenity-based housing affordability indexes. Real Estate Economics 37 (4), 705-746. 
Fleming, D. A, McGranahan, D. A., Goetz, S. J., 2009. Natural amenities and rural development: The role of land-based policies. Rural Development Paper no. 45. The Northeast Regional Center for Rural Development, Pennsylvania State University.

Freeman III, A.M., 1979. Hedonic prices, property values and measuring environmental benefits: A survey of the issues. Scandinavian Journal of Economics 81 (2), 154-173.

Fuguitt, G.V., Beale, C.L., 1996. Recent trends in nonmetropolitan migration: Toward a new turnaround? Growth and Change 27 (2), 156-174.

Fuller, K., Monson, M., Ward, J., Mathews, L.G., 2005. Can nature drive economic growth? Review of Agricultural Economics 27 (4), 621-629.

Garrod, G., Willis, K., 1992. The amenity value of woodland in Great Britain: A comparison of economic estimates. Environmental \& Resource Economics 2 (4), 415-434.

Geoghegan, J., 2002. The value of open spaces in residential land use. Land Use Policy 19 (1), 91-98.

Geoghegan, J., Lynch, L., Bucholtz, S., 2003. Capitalization of open spaces into housing values and the residential property tax revenue impacts of agricultural easement programs. Agricultural and Resource Economics Review 32 (1), 33-45.

Geoghegan, J., Wainger, L.A., Bockstael, N.E., 1997. Spatial landscape indices in a hedonic framework: An ecological economics analysis using GIS. Ecological Economics 23 (3), 251-264.

Gottlieb, P.D., 1995. Residential amenities, firm location and economic development. Urban Studies 32 (9), 1413-1436.

Graves, P.E., 1980. Migration and climate. Journal of Regional Science 20 (2), 227-237.

Graves, P.E., Knapp, T.A., 1985. Hedonic analysis in a spatial context: Theoretical problems in valuing location-specific amenities. Economic Record 61, 737-743.

Graves, P.E., Linneman, P.D., 1979. Household migration: Theoretical and empirical results. Journal of Urban Economics 6 (3), 383-404.

Graves, P.E., Mueser, P.R., 1993. The role of equilibrium and disequilibrium in modeling regional growth and decline: a critical reassessment. Journal of Regional Science 33 (1), 69-84.

Green, G.P., 2001. Amenities and community economic development: Strategies for sustainability. Journal of Regional Analysis and Policy 31 (2), 61-76.

Greenwood, M.J., 1985. Human migration: theory, models, and empirical studies. Journal of Regional Science 25 (4), 521-544. 
Greenwood, M.J., Hunt, G.L., 1989. Jobs versus amenities in the analysis of metropolitan migration. Journal of Urban Economics 25 (1), 1-16.

Greenwood, M.J., Hunt, G.L., Rickman, D.S., Treyz, G.I., 1991. Migration, regional equilibrium, and the estimation of compensating differentials. American Economic Review 81 (5), 1382-1390.

Hailu, Y.G., Rosenberger, R.S., 2004. Modeling migration effects on agricultural lands: A growth equilibrium model. Agricultural and Resource Economics Review 33 (1), 50-60.

Hand, M.S., Thacher, J.A., McCollum, D.W., Berrens, R.P., 2008. Intra-regional amenities, wages, and home prices: The role of forests in the southwest. Land Economics 84 (4), 635-651.

Hardie, I., Lichtenberg, E., Nickerson, C.J., 2007. Regulation, open space, and the value of land undergoing residential subdivision. Land Economics 83 (4), 458-474.

Harrison Jr, D., Rubinfeld, D.L., 1978. Hedonic housing prices and the demand for clean air. Journal of Environmental Economics and Management 5 (1), 81-102.

Hellerstein, D., Nickerson, C., Cooper, J., Feather, P., Gadsby, D., Mullarkey, D., Tegene, A., Barnard, C., 2002. Farmland protection: The role of public preferences for rural amenities, USDA Agricultural Economic Report No. 815. United States Department of Agriculture, Washington, D.C.

Holloway, G., Lacombe, D., LeSage, J.P., 2007. Spatial econometric issues for bio-economic and land-use modelling. Journal of Agricultural Economics 58 (3), 549-588.

Huffman, W.E., Feridhanusetyawan, T., 2007. Migration, fixed costs, and location-specific amenities: A hazard analysis for a panel of males. American Journal of Agricultural Economics 89 (2), 368-382.

Hunt, G.L., 1993. Equilibrium and disequilibrium in migration modelling. Regional Studies 27 (4), 341-349.

Irwin, E.G., 2002. The effects of open space on residential property values. Land Economics 78 (4), 465-480.

Irwin, E.G., Bockstael, N.E., 2001. The problem of identifying land use spillovers:

Measuring the effects of open space on residential property values. American Journal of Agricultural Economics 83 (3), 698-704.

Jeppesen, T., List, J.A., Folmer, H., 2002. Environmental regulations and new plant location decisions: Evidence from a meta-analysis. Journal of Regional Science 42 (1), 19-49. 
Johnson, J.D., Rasker, R., 1993. Local government: Local business climate and quality of life. Montana Policy Review 3, 11-19.

Johnston, R.J., Opaluch, J.J., Grigalunas, T.A., Mazzotta, M.J., 2001. Estimating amenity benefits of coastal farmland. Growth and Change 32 (3), 305-325.

Judson, D.H., Reynolds-Scanlon, S., Popoff, C.L., 1999. Migrants to Oregon in the 1990's: Working age, near-retirees, and retirees make different destination choices. Rural Development Perspectives 14 (2), 24-31.

Kim, K.K., Marcouiller, D.W., Deller, S.C., 2005. Natural amenities and rural development: Understanding spatial and distributional attributes. Growth and Change 36 (2), 273-297.

Kim, Y.S., Johnson, R.L., 2002. The impact of forests and forest management on neighboring property values. Society and Natural Resources 15 (10), 887-901.

Kline, J., Wichelns, D., 1994. Using referendum data to characterize public support for purchasing development rights to farmland. Land Economics 70 (2), 223-233.

Knapp, T.A., Graves, P.E., 1989. On the role of amenities in models of migration and regional development. Journal of Regional Science 29 (1), 71-87.

Kotchen, M.J., Powers, S.M., 2006. Explaining the appearance and success of voter referenda for open-space conservation. Journal of Environmental Economics and Management 52 (1), 373-390.

Kuminoff, N.V., 2009. Using a bundled amenity model to estimate the value of cropland open space and determine an optimal buffer zone. Journal of Agricultural and Resource Economics 34 (1), 68-90.

Lee, C.-M., Linneman, P., 1998. Dynamics of the greenbelt amenity effect on the land market: The case of Seoul's Greenbelt. Real Estate Economics 26 (1), 107-129.

Leggett, C.G., Bockstael, N.E., 2000. Evidence of the effects of water quality on residential land prices. Journal of Environmental Economics and Management 39 (2), 121-144.

Lewis, D.J., Hunt, G.L., Plantinga, A.J., 2002. Public conservation land and employment growth in the Northern Forest region. Land Economics 78 (2), 245-259.

Lewis, D.J., Hunt, G.L., Plantinga, A.J., 2003. Does public lands policy affect local wage growth? Growth and Change 34 (1), 64-86.

Lundgren, T., 2009. Environmental protection and impact on adjacent economies: Evidence from the Swedish mountain region. Growth and Change 40 (3), 513-532.

Luttik, J., 2000. The value of trees, water and open space as reflected by house prices in the Netherlands. Landscape and Urban Planning 48 (3-4), 161-167. 
Lutzenhiser, M., Netusil, N.R., 2001. The effect of open spaces on a home's sale price. Contemporary Economic Policy 19 (3), 291-298.

Mahan, B.L., Polasky, S., Adams, R.M., 2000. Valuing urban wetlands: A property price approach. Land Economics 76 (1), 100-113.

Mansfield, C., Pattanayak, S.K., McDow, W., McDonald, R., Halpin, P., 2005. Shades of green: Measuring the value of urban forests in the housing market. Journal of Forest Economics 11 (3), 177-199.

Marcouiller, D.W., Clendenning, G., 2005. The supply of natural amenities: Moving from empirical anecdotes to a theoretical basis, in: Green, G.P., Deller, S.C., Marcouiller, D.W. (Eds.), Amenities and rural development: Theory, methods and public policy. Edward Elgar, Cheltenham UK, pp. 6-32.

Matsuoka, R.H., Kaplan, R., 2008. People needs in the urban landscape: Analysis of Landscape and Urban Planning contributions. Landscape and Urban Planning 84 (1), 7 19.

McConnell, V., Walls, M., 2005. The value of open space: Evidence from studies of nonmarket benefits. Resources for the Future, Washington.

McGranahan, D., Wojan, T., 2007. Recasting the creative class to examine growth processes in rural and urban counties. Regional Studies 41 (2), 197-216.

McGranahan, D.A., 2008. Landscape influence on recent rural migration in the US. Landscape and Urban Planning 85 (3-4), 228-240.

Milburn, L.S., Brown, R., Mulley, S.J., '...Silver in the stars and gold in the morning sun’: Non-farm rural landowners' motivations for rural living and attachment to their land. Landscape Research 35 (1), 27-46.

Mueser, P.R., Graves, P.E., 1995. Examining the role of economic opportunity and amenities in explaining population redistribution. Journal of Urban Economics 37 (2), 176-200.

Munroe, D.K., 2007. Exploring the determinants of spatial pattern in residential land markets: Amenities and disamenities in Charlotte, NC, USA. Environment and Planning B: Planning and Design 34 (2), 336-354.

Nelson, A.C., 1986. Using land markets to evaluate urban containment programs. Journal of the American Planning Association 52 (2), 156-171.

Nelson, E., Uwasu, M., Polasky, S., 2007. Voting on open space: What explains the appearance and support of municipal-level open space conservation referenda in the United States? Ecological Economics 62 (3-4), 580-593. 
Netusil, N.R., 2005. The effect of environmental zoning and amenities on property values: Portland, Oregon. Land Economics 81 (2), 227-246.

Neumann, B.C., Boyle, K.J., Bell, K.P., 2009. Property price effects of a national wildlife refuge: Great Meadows National Wildlife Refuge in Massachusetts. Land Use Policy 26 (4), 1011-1019.

Nicholls, S., Crompton, J.L., 2005. The impact of greenways on property values: Evidence from Austin, Texas. Journal of Leisure Research 37 (3), 321-341.

Nzaku, K., Bukenya, J.O., 2005. Examining the relationship between quality of life amenities and economic development in the Southeast USA. Review of Urban and Regional Development Studies 17 (2), 89-103.

Palmquist, R.B., Roka, F.M., Vukina, T., 1997. Hog operations, environmental effects, and residential property values. Land Economics 73 (1), 114-124.

Park, J.R., Stabler, M.J., Jones, P.J., Mortimer, S.R., Tiffin, J.R., Tranter, R.B., 2009. Evaluating the role of environmental quality in the sustainable rural economic development of England. Environment, Development and Sustainability 11 (4), 735-750.

Partridge, M.D., Rickman, D.S., Ali, K., Olfert, M.R., 2008. The geographic diversity of U.S. nonmetropolitan growth dynamcis: A Geographically Weighted Regression approach. Land Economics 84 (2), 241-266.

Paterson, R.W., Boyle, K.J., 2002. Out of sight, out of mind? Using GIS to incorporate visibility in hedonic property value models. Land Economics 78 (3), 417-425.

Pimentel, D., Harvey, C., Resosudarmo, P., Sinclair, K., Kurz, D., McNair, M., Crist, S., Shpritz, L., Fitton, L., Saffouri, R., Blair, R., 1995. Environmental and economic costs of soil erosion and conservation benefits. Science 267 (5201), 1117-1123.

Porell, F.W., 1982. Intermetropolitan migration and quality of life. Journal of Regional Science 22 (29), 137-158.

Poudyal, N.C., Hodges, D.G., Cordell, H.K., 2008. The role of natural resource amenities in attracting retirees: Implications for economic growth policy. Ecological Economics 68 (1-2), 240-248.

Poudyal, N.C., Hodges, D.G., Fenderson, J., Tarkington, W., 2010. Realizing the economic value of a forested landscape in a viewshed. Southern Journal of Applied Forestry 34 (2), 72-78.

Poudyal, N.C., Hodges, D.G., Merrett, C.D., 2009. A hedonic analysis of the demand for and benefits of urban recreation parks. Land Use Policy 26 (4), 975-983. 
Poudyal, N.C., Hodges, D.G., Tonn, B., Cho, S.H., 2009. Valuing diversity and spatial pattern of open space plots in urban neighborhoods. Forest Policy and Economics 11 (3), 194-201.

Power, T.M., Barrett, R.N., 2001. Post-cowboy economics: Pay and prosperty in the new American West. Island Press, Washington.

Rasker, R., 2006. An exploration into the economic impact of industrial development versus conservation on western public lands. Society and Natural Resources 19 (3), 191-207.

Ready, R.C., Abdalla, C.W., 2005. The amenity and disamenity impacts of agriculture:

Estimates from a hedonic pricing model. American Journal of Agricultural Economics 87 (2), 314-326.

Redfearn, C.L., 2009. How informative are average effects? Hedonic regression and amenity capitalization in complex urban housing markets. Regional Science and Urban Economics 39 (3), 297-306.

Reeder, R.J., 1998. Retiree-attraction policies for rural development. Agriculture Information Bulletin No. 741. Food and Rural Economics Division, Economic Research Service, U.S. Department of Agriculture, Washington.

Riddel, M., 2001. A dynamic approach to estimating hedonic prices for environmental goods: An application to open space purchase. Land Economics 77 (4), 494-512.

Roback, J., 1982. Wages, rents, and the quality of life. Journal of Political Economy 90 (6), 1257-1278.

Roback, J., 1988. Wages, rents, and amenities - differences among workers and regions. Economic Inquiry 26 (1), 23-41.

Rosen, S., 1974. Hedonic prices and implicit markets - product differentiation in pure competition. Journal of Political Economy 82 (1), 34-55.

Rupasingha, A., Goetz, S.J., 2004. County amenities and net migration. Agricultural and Resource Economics Review 33 (2), 245-254.

Sander, H.A., Polasky, S., 2009. The value of views and open space: Estimates from a hedonic pricing model for Ramsey County, Minnesota, USA. Land Use Policy 26 (3), 837-845.

Shultz, S.D., King, D.A., 2001. The use of census data for hedonic price estimates of openspace amenities and land use. Journal of Real Estate Finance and Economics 22 (2-3), 239-252. 
Skelley, B.D., 2004. Retiree-attraction policies: Challenges for local governance in rural regions. Public Administration and Management: An Interactive Journal 9 (3), 212-223.

Smith, V.K., Poulos, C., Kim, H., 2002. Treating open space as an urban amenity. Resource and Energy Economics 24 (1-2), 107-129.

Steinnes, D.N., Fisher, W.D., 1974. Econometric model of intraurban location. Journal of Regional Science 14 (1), 65-80.

Tajima, K., 2003. New estimates of the demand for urban green space: Implications for valuing the environmental benefits of Boston's big dig project. Journal of Urban Affairs $25(5), 641-655$.

Tapsuwan, S., Ingram, G., Burton, M., Brennan, D., 2009. Capitalized amenity value of urban wetlands: A hedonic property price approach to urban wetlands in Perth, Western Australia. Australian Journal of Agricultural and Resource Economics 53 (4), 527-545.

Thorsnes, P., 2002. The value of a suburban forest preserve: Estimates from sales of vacant residential building lots. Land Economics 78 (3), 426-441.

Tyrväinen, L., 1997. The amenity value of the urban forest: An application of the hedonic pricing method. Landscape and Urban Planning 37 (3-4), 211-222.

Tyrväinen, L., Miettinen, A., 2000. Property prices and urban forest amenities. Journal of Environmental Economics and Management 39 (2), 205-223.

USEPA, 2009. Valuing the protection of ecological systems and services. A report of the EPA Science Advisory Board. United States Environmental Protection Agency.

Vanslembrouck, I., Van Huylenbroeck, G., Van Meensel, J., 2005. Impact of agriculture on rural tourism: A hedonic pricing approach. Journal of Agricultural Economics 56 (1), 17 30.

Vogt, C.A., Marans, R.W., 2004. Natural resources and open space in the residential decision process: a study of recent movers to fringe counties in southeast Michigan. Landscape and Urban Planning 69 (2-3), 255-269.

Walsh, R., 2007. Endogenous open space amenities in a locational equilibrium. Journal of Urban Economics 61 (2), 319-344.

White, E.M., Leefers, L.A., 2007. Influence of natural amenities on residential property values in a rural setting. Society and Natural Resources 20 (7), 659-667.

Williams, J.D., 1981. The nonchanging determinants of nonmetropolitan migration. Rural Sociology 46 (2), 183-202. 
Wu, J.J., 2006. Environmental amenities, urban sprawl, and community characteristics. Journal of Environmental Economics and Management 52 (2), 527-547.

Wu, J.J., Gopinath, M., 2008. What causes spatial variations in economic development in the United States? American Journal of Agricultural Economics 90 (2), 392-408. 


\section{Table 1}

Reported effects of amenity, economic opportunity, and fiscal variables on population, employment, and income: Frequencies ${ }^{\mathrm{a}}$

\begin{tabular}{|c|c|c|c|c|c|c|c|c|c|c|c|c|}
\hline & \multicolumn{3}{|c|}{ Amenity effects } & \multicolumn{3}{|c|}{$\begin{array}{l}\text { Effects of high wages / } \\
\text { income }\end{array}$} & \multicolumn{3}{|c|}{$\begin{array}{l}\text { Effects of low } \\
\text { unemployment }\end{array}$} & \multicolumn{3}{|c|}{ Effects of low taxes } \\
\hline & No. obs. ${ }^{b}$ & Sig. ${ }^{\mathrm{c}}$ & Neg. sig. ${ }^{d}$ & No. obs. & Sig. & Neg. sig. & No. obs. & Sig. & Neg. sig. & No. obs. & Sig. & Neg. sig. \\
\hline Population & 12 & 5 & 2 & 3 & 2 & 1 & 3 & 0 & 2 & 8 & 4 & 0 \\
\hline Migration & 14 & 5 & 0 & 12 & 2 & 2 & 7 & 0 & 0 & 4 & 2 & 1 \\
\hline Sum & 26 & 10 & 2 & 15 & 4 & 3 & 10 & 0 & 2 & 12 & 6 & 1 \\
\hline Employment (E.) & 12 & 5 & 0 & 7 & 1 & 3 & 6 & 2 & 1 & 6 & 3 & 0 \\
\hline E. in the resource sector & 4 & 0 & 0 & 3 & 0 & 1 & 3 & 0 & 0 & 4 & 1 & 0 \\
\hline E. in other spec. sect. & 7 & 2 & 0 & 4 & 0 & 2 & 3 & 0 & 3 & 5 & 1 & 0 \\
\hline Sum & 23 & 7 & 0 & 14 & 1 & 6 & 12 & 2 & 4 & 15 & 5 & 0 \\
\hline Income (per capita) & 7 & 2 & 0 & 4 & 0 & 4 & 3 & 3 & 0 & 6 & 2 & 1 \\
\hline Other income variable & 4 & 2 & 0 & 0 & 0 & 0 & 1 & 0 & 0 & 0 & 0 & 0 \\
\hline Sum & 11 & 4 & 0 & 4 & 0 & 4 & 4 & 3 & 0 & 6 & 2 & 1 \\
\hline TOTAL & 60 & 21 & 2 & 33 & 5 & 13 & 26 & 5 & 6 & 33 & 13 & 2 \\
\hline in $\%$ & 100.0 & 35.0 & 3.3 & 100.0 & 15.2 & 39.4 & 100.0 & 19.2 & 23.1 & 100.0 & 39.4 & 6.1 \\
\hline
\end{tabular}

${ }^{\text {a }}$ The sample is given in Appendix A.

${ }^{\mathrm{b}}$ Number of estimates containing the respective dependent and independent variable.

${ }^{\mathrm{c}}$ Number of estimates with coefficients that are positive and significant on the 5\% level (see Appendix A).

${ }^{d}$ Number of estimates that are negative and significant on the $5 \%$ level (see Appendix A). 
Table 2

Frequency of significant and robust reported amenity effects in the HP studies ${ }^{\mathrm{a}}$

\begin{tabular}{|c|c|c|c|c|c|c|c|}
\hline & \multicolumn{7}{|c|}{ Landscape amenity variables: Frequencies ${ }^{\mathrm{b}}$} \\
\hline & Open space & Forest & Preserve & Wetland & Agriculture & Diversity & Sum \\
\hline Sample size & 30 & 20 & 11 & 6 & 9 & 8 & 84 \\
\hline Effect significant & 15 & 9 & 9 & 3 & 2 & 6 & 44 \\
\hline Effect robust & 7 & 3 & 4 & 1 & 0 & 4 & 19 \\
\hline
\end{tabular}

${ }^{\mathrm{a}}$ The sample is given in Appendix B.

${ }^{\mathrm{b}}$ See section 5.1 for definitions of the variables. 
Appendix A. Survey sample migration and regional economic studies ${ }^{\mathrm{a}}$

\begin{tabular}{|c|c|c|c|c|c|c|c|c|c|c|}
\hline \multirow[t]{2}{*}{ Author(s) } & \multirow[t]{2}{*}{ Journal } & \multirow[t]{2}{*}{ Dependent variable $^{b}$} & \multirow[t]{2}{*}{$\mathrm{L}$} & \multirow[t]{2}{*}{ Model $^{\mathrm{c}}$} & \multicolumn{4}{|c|}{ Independent variables } & \multirow[t]{2}{*}{ Autocr. } & \multirow[t]{2}{*}{ Estimation $^{f}$} \\
\hline & & & & & Amenity $^{\mathrm{d}}$ & $\operatorname{Tax}^{\mathrm{e}}$ & Wage $^{e}$ & Unempl. $^{\mathrm{e}}$ & & \\
\hline Ali et al., 2007 & IRSR & Pop & 0 & $\mathrm{RE}$ & 0 & -- & -- & -- & 1 & $\begin{array}{l}\text { OLS, SEM / } \\
\text { MLE }\end{array}$ \\
\hline Boarnet et al., 2005 & PRS & Pop & 0 & $\mathrm{RE} / \mathrm{SEQ}$ & 1 & -- & -- & -- & 1 & IV \\
\hline Boarnet et al., 2005 & PRS & Empl & 0 & $\mathrm{RE} / \mathrm{SEQ}$ & 0 & -- & -- & -- & 1 & IV \\
\hline Booth, 1999 & $\mathrm{GC}$ & Pop & 1 & $\mathrm{RE}$ & 1 & -- & -- & -- & 0 & OLS \\
\hline Booth, 1999 & $\mathrm{GC}$ & Empl & 1 & $\mathrm{RE}$ & 0 & -- & -- & -- & 0 & OLS \\
\hline Booth, 1999 & $\mathrm{GC}$ & Inc & 1 & $\mathrm{RE}$ & 0 & -- & -- & -- & 0 & OLS \\
\hline Booth, 1999 & $\mathrm{GC}$ & Inc (wage) & 1 & $\mathrm{RE}$ & 1 & -- & -- & -- & 0 & OLS \\
\hline Booth, 1999 & $\mathrm{GC}$ & Inc (dividend) & 1 & $\mathrm{RE}$ & 0 & -- & -- & -- & 0 & OLS \\
\hline Booth, 1999 & $\mathrm{GC}$ & Inc (transfer) & 1 & $\mathrm{RE}$ & 1 & -- & -- & -- & 0 & OLS \\
\hline Clark and Hunter, 1992 & JRS & NetMig (age $>40)$ & 1 & $\mathrm{MIG} / \mathrm{LC}$ & 1 & 1 & {$[-]$} & 0 & 0 & OLS \\
\hline Clark and Hunter, 1992 & JRS & NetMig (age $\leq 40)$ & 1 & $\mathrm{MIG} / \mathrm{LC}$ & 0 & {$[-]$} & {$[-]$} & 0 & 0 & OLS \\
\hline Deller and Lledo, 2007 & ARER & Pop & 0 & $\mathrm{RE}$ & 0 & 1 & - & -- & 0 & BMA \\
\hline Deller and Lledo, 2007 & ARER & Empl & 0 & $\mathrm{RE}$ & 1 & 1 & -- & -- & 0 & BMA \\
\hline Deller and Lledo, 2007 & ARER & Inc (per capita) & 0 & $\mathrm{RE}$ & 1 & {$[-]$} & {$[-]$} & 1 & 0 & BMA \\
\hline Deller et al., 2001 & AJAE & Pop & 0 & $\mathrm{RE}$ & 1 & 1 & {$[-]$} & {$[-]$} & 0 & OLS \\
\hline Deller et al., 2001 & AJAE & Empl & 0 & $\mathrm{RE}$ & 1 & 0 & {$[-]$} & 1 & 0 & OLS \\
\hline Deller et al., 2001 & AJAE & Inc (per capita) & 0 & $\mathrm{RE}$ & 0 & 1 & {$[-]$} & 1 & 0 & OLS \\
\hline Duffy-Deno, 1997a & GC & Pop & 0 & RE / SEQ & 0 & 1 & -- & -- & 0 & $2 \mathrm{SLS}$ \\
\hline Duffy-Deno, 1997a & $\mathrm{GC}$ & Empl (non-resource) & 0 & RE / SEQ & 0 & 0 & {$[-]$} & {$[-]$} & 0 & 2SLS \\
\hline Duffy-Deno, 1997a & $\mathrm{GC}$ & Empl (resource) & 0 & RE / SEQ & 0 & 0 & 0 & 0 & 0 & 2SLS \\
\hline Duffy-Deno, 1997b & JLR & Pop & 1 & $\mathrm{RE} / \mathrm{SEQ}$ & 1 & 0 & -- & -- & 0 & 2SLS \\
\hline Duffy-Deno, 1997b & JLR & Empl (non-resource) & 1 & RE / SEQ & 1 & 0 & {$[-]$} & {$[-]$} & 0 & 2SLS \\
\hline Duffy-Deno, 1997b & JLR & Empl (resource) & 1 & RE / SEQ & 0 & 0 & {$[-]$} & 0 & 0 & 2SLS \\
\hline Duffy-Deno, 1998 & JRS & Pop & 1 & RE / SEQ & 0 & 1 & -- & -- & 0 & 2SLS \\
\hline
\end{tabular}


(Appendix A, continued)

\begin{tabular}{|c|c|c|c|c|c|c|c|c|c|c|}
\hline \multirow[t]{2}{*}{ Author(s) } & \multirow[t]{2}{*}{ Journal } & \multirow[t]{2}{*}{ Dependent variable $^{b}$} & \multirow[t]{2}{*}{$\mathrm{L}$} & \multirow[t]{2}{*}{ Model $^{\mathrm{c}}$} & \multicolumn{4}{|c|}{ Independent variables } & \multirow[t]{2}{*}{ Autocr. } & \multirow[t]{2}{*}{ Estimation $^{f}$} \\
\hline & & & & & Amenity $^{\mathrm{d}}$ & $\operatorname{Tax}^{\mathrm{e}}$ & Wage $^{\mathrm{e}}$ & Unempl. $^{\mathrm{e}}$ & & \\
\hline Duffy-Deno, 1998 & JRS & Empl (non-resource) & 1 & $\mathrm{RE} / \mathrm{SEQ}$ & 0 & 0 & 0 & {$[-]$} & 0 & $2 \mathrm{SLS}$ \\
\hline Duffy-Deno, 1998 & JRS & Empl (resource) & 1 & RE / SEQ & 0 & 1 & 0 & 0 & 0 & 2SLS \\
\hline Duffy-Deno, 1998 & JRS & Empl & 1 & $\mathrm{RE} / \mathrm{SEQ}$ & 0 & 0 & 0 & {$[-]$} & 0 & 2SLS \\
\hline Ferguson et al., 2007 & $\mathrm{GC}$ & NetMig & 1 & $\mathrm{RE} / \mathrm{MIG}$ & 0 & -- & 0 & -- & 1 & WLS, SEM \\
\hline Gottlieb, 1995 & US & Empl (high-tech) & 1 & $\mathrm{RE} / \mathrm{FL}$ & 0 & -- & -- & -- & 1 & $\begin{array}{l}\text { Tobit / MLE, } \\
\text { logit / min chi- } \\
\text { square }\end{array}$ \\
\hline Greenwood and Hunt, 1989 & JUE & NetMig & 1 & RE / SEQ & 0 & -- & 0 & 0 & 0 & $\begin{array}{l}\text { OLS, 2SLS, } \\
\text { 3SLS }\end{array}$ \\
\hline Hailu and Rosenberger, 2004 & ARER & Pop & 0 & RE / SEQ & $0[-]$ & 0 & -- & {$[-]$} & 0 & 2SLS \\
\hline Hailu and Rosenberger, 2004 & ARER & Empl & 0 & RE / SEQ & 1 & 0 & -- & -- & 0 & 2SLS \\
\hline Kim et al., 2005 & $\mathrm{GC}$ & Pop & 0 & RE & 0 & 0 & -- & -- & 1 & SEM, MLE \\
\hline Kim et al., 2005 & $\mathrm{GC}$ & Empl (service) & 0 & $\mathrm{RE}$ & 0 & 0 & -- & -- & 1 & SEM, MLE \\
\hline Kim et al., 2005 & $\mathrm{GC}$ & Inc (per capita) & 0 & $\mathrm{RE}$ & 0 & 0 & -- & -- & 1 & SEM, MLE \\
\hline Lewis et al., 2002 & LE & Empl & 0 & $\mathrm{RE} / \mathrm{SEQ}$ & 0 & -- & -- & 0 & 1 & 3SLS \\
\hline Lewis et al., 2002 & LE & NetMig & 1 & RE / SEQ & 1 & -- & 0 & -- & 1 & 3SLS \\
\hline Lewis et al., 2003 & $\mathrm{GC}$ & Empl & 0 & $\mathrm{RE} / \mathrm{SEQ}$ & 0 & -- & -- & 0 & 1 & 3SLS \\
\hline Lewis et al., 2003 & $\mathrm{GC}$ & NetMig & 1 & RE / SEQ & 1 & -- & 0 & -- & 1 & 3SLS \\
\hline Lewis et al., 2003 & GC & Inc (wage per capita) & 0 & RE / SEQ & 0 & -- & -- & 0 & 1 & $3 \mathrm{SLS}$ \\
\hline Lundgren, 2009 & $\mathrm{GC}$ & NetMig & 1 & RE / SEQ & 0 & 0 & -- & -- & 0 & IV, GMM \\
\hline Lundgren, 2009 & $\mathrm{GC}$ & Empl (forest sector) & 1 & RE / SEQ & 0 & 0 & -- & -- & 0 & IV, GMM \\
\hline Lundgren, 2009 & $\mathrm{GC}$ & Empl (tourism sector) & 1 & RE / SEQ & 0 & 1 & -- & -- & 0 & IV, GMM \\
\hline Lundgren, 2009 & GC & Inc (per capita) & 0 & $\mathrm{RE} / \mathrm{SEQ}$ & 0 & 0 & -- & -- & 0 & IV, GMM \\
\hline McGranahan, 2008 & LUP & NetMig & 1 & RE / SEQ & 0 & -- & 1 & -- & 1 & 3SLS, OLS \\
\hline McGranahan, 2008 & LUP & Empl & 0 & RE / SEQ & 1 & -- & {$[-]$} & -- & 1 & 3SLS, OLS \\
\hline
\end{tabular}


(Appendix A, continued)

\begin{tabular}{|c|c|c|c|c|c|c|c|c|c|c|}
\hline \multirow[t]{2}{*}{ Author(s) } & \multirow[t]{2}{*}{ Journal } & \multirow[t]{2}{*}{ Dependent variable $^{b}$} & \multirow[t]{2}{*}{$\mathrm{L}$} & \multirow[t]{2}{*}{ Model $^{\mathrm{c}}$} & \multicolumn{4}{|c|}{ Independent variables } & \multirow[t]{2}{*}{ Autocr. } & \multirow[t]{2}{*}{ Estimation $^{1}$} \\
\hline & & & & & Amenity $^{\mathrm{d}}$ & $\operatorname{Tax}^{\mathrm{e}}$ & Wage $^{\mathrm{e}}$ & Unempl. $^{\mathrm{e}}$ & & \\
\hline McGranahan and Wojan, 2007 & RS & NetMig & 0 & RE / SEQ & 0 & -- & 0 & -- & 0 & 3SLS, OLS \\
\hline McGranahan and Wojan, 2007 & $\mathrm{RS}$ & Empl (total) & 0 & $\mathrm{RE} / \mathrm{SEQ}$ & 0 & -- & {$[-]$} & -- & 0 & 3SLS, OLS \\
\hline McGranahan and Wojan, 2007 & $\mathrm{RS}$ & Empl (creative class) & 0 & $\mathrm{RE} / \mathrm{SEQ}$ & 1 & -- & 0 & -- & 0 & 3SLS, OLS \\
\hline Nzaku and Bukenya, 2005 & RURDS & Pop & 0 & $\mathrm{RE} / \mathrm{SEQ}$ & {$[-]$} & -- & 1 & 0 & 1 & SLM, MLE \\
\hline Nzaku and Bukenya, 2005 & RURDS & Empl & 0 & RE / SEQ & -- & 1 & 0 & 1 & 1 & SLM, MLE \\
\hline Nzaku and Bukenya, 2005 & RURDS & Inc (per capita) & 0 & $\mathrm{RE} / \mathrm{SEQ}$ & -- & 0 & {$[-]$} & 1 & 1 & SLM, MLE \\
\hline Park et al., 2009 & EDS & Pop & 0 & RE / SEQ & 1 & 0 & 1 & -- & 0 & OLS \\
\hline Park et al., 2009 & EDS & Empl & 0 & $\mathrm{RE} / \mathrm{SEQ}$ & 0 & 1 & 0 & -- & 0 & OLS \\
\hline Park et al., 2009 & EDS & Inc & 0 & RE / SEQ & 0 & 1 & {$[-]$} & -- & 0 & OLS \\
\hline Porell, 1982 & JRS & InMig & 1 & $\mathrm{MIG} / \mathrm{GR}$ & 1 & -- & 1 & 0 & 0 & OLS \\
\hline Porell, 1982 & JRS & OutMig & 1 & MIG / GR & 0 & -- & 0 & 0 & 0 & OLS \\
\hline Poudyal et al., 2008 & $\mathrm{EE}$ & NetMig (Retirees) & 1 & $\mathrm{RE} / \mathrm{MIG}$ & 1 & 1 & -- & -- & 0 & 3SLS \\
\hline Rasker, 2006 & SNR & Inc (per capita) & 0 & $\mathrm{RE}$ & 1 & -- & -- & -- & 0 & OLS \\
\hline Williams, 1981 & $\mathrm{RS}$ & InMig & 1 & MIG / SEQ & 0 & -- & 0 & 0 & 0 & 3SLS, OLS \\
\hline Williams, 1981 & $\mathrm{RS}$ & OutMig & 1 & MIG / SEQ & 0 & -- & 0 & 0 & 0 & 3SLS, OLS \\
\hline Williams, 1981 & $\mathrm{RS}$ & Empl & 0 & MIG / SEQ & 1 & -- & 1 & 0 & 0 & 3SLS, OLS \\
\hline
\end{tabular}

${ }^{a}$ Column headings: $\mathrm{L}=$ levels specification $(1=$ levels, $0=$ flow $)$, Tax $=$ effect of low local tax rates, Wage $=$ effect of high average wage $/$ income, Unempl.=effect of low local unemployment, Autocr.=test for spatial autocorrelation or spatial econometric model $(1=$ yes, $0=$ no $)$.

${ }^{\mathrm{b}} \mathrm{Pop}=$ population, Empl=employment, Inc=income, NetMig=net migration, InMig=in-migration, OutMig=out-migration.

${ }^{\mathrm{c}} \mathrm{RE}=$ regional economic / urban economic, $\mathrm{MIG}=$ migration, $\mathrm{LC}=$ life-cycle, $\mathrm{SEQ}=$ system of equations, $\mathrm{FL}=$ firm location decision, $\mathrm{GR}=$ gravity.

${ }^{\mathrm{d}} 1=$ at least $50 \%$ of amenity coefficients in model are positive and significant on the $5 \%$ level, $0=$ non-significant, [-]=negative and significant.

e $1=$ positive and significant on the $5 \%$ level, $0=$ non-significant, $[-]=$ negative and significant.

${ }^{\mathrm{f}} \mathrm{BMA}=$ Bayesian modeling average, GMM=general method of moments, IV=instrumental variables technique (spatially explicit), MLE=maximum likelihood estimator, OLS=ordinary least squares, $\mathrm{SEM}=$ spatial error model, $\mathrm{SLM}=$ spatial lag model, 2SLS=two stage least squares, $3 \mathrm{SLS}=$ three stage least squares, WLS=weighted least squares. 
Appendix B. Survey sample hedonic pricing estimates

\begin{tabular}{|c|c|c|c|c|}
\hline Author(s) & Journal & Amenity $^{\mathrm{a}}$ & $\begin{array}{l}\text { Significant } \\
\text { and positive } \\
\text { effect }^{\text {b }}\end{array}$ & $\begin{array}{l}\text { Robust } \\
\text { effect }^{\text {b }}\end{array}$ \\
\hline Acharya and Bennet, 2001 & JREFE & open space & 1 & 1 \\
\hline Acharya and Bennet, 2001 & JREFE & diversity & 0 & 0 \\
\hline Anderson and West, 2006 & RSUE & open space & 1 & 0 \\
\hline Anderson and West, 2006 & RSUE & preserve & 1 & 0 \\
\hline Asabere and Huffman, 2009 & JREFE & open space & 1 & 1 \\
\hline Bastian et al., 2002 & $\mathrm{EE}$ & diversity & 1 & 1 \\
\hline Bastian et al., 2002 & $\mathrm{EE}$ & preserve & 0 & 0 \\
\hline Benefield, 2009 & PM & forest & 0 & 0 \\
\hline Bockstael, 1996 & AJAE & preserve & 1 & 1 \\
\hline Bockstael, 1996 & AJAE & forest & 0 & 0 \\
\hline Bockstael, 1996 & AJAE & agriculture & 1 & 0 \\
\hline Bohlen and Lewis, 2009 & JEM & open space & 1 & 0 \\
\hline Bohlen and Lewis, 2009 & JEM & diversity & 1 & 0 \\
\hline Cheshire and Sheppard, 1995 & $\mathrm{EC}$ & open space & 1 & 0 \\
\hline Cho et al., 2006 & JARE & open space & 1 & 1 \\
\hline Cho et al., 2008 & $\mathrm{EE}$ & forest & 1 & 0 \\
\hline Cho et al., 2008 & $\mathrm{EE}$ & diversity & 1 & 1 \\
\hline Cho et al., 2009 & $\mathrm{EE}$ & preserve & 1 & 1 \\
\hline Doss and Taff, 1996 & JARE & wetland & 1 & 0 \\
\hline Fisher et al, 2009 & RealEE & open space & 1 & 1 \\
\hline Garrod and Willis, 1992 & ERE & forest & 1 & 0 \\
\hline Geoghegan et al., 1997 & $\mathrm{EE}$ & open space & 0 & 0 \\
\hline Geoghegan et al., 1997 & $\mathrm{EE}$ & diversity & 0 & 0 \\
\hline Geoghegan, 2002 & LUP & open space & 1 & 0 \\
\hline Geoghegan et al., 2003 & ARER & open space & 0 & 0 \\
\hline Geoghegan et al., 2003 & ARER & open space & 0 & 0 \\
\hline Geoghegan et al., 2003 & ARER & open space & 1 & 0 \\
\hline Hand et al., 2008 & LE & preserve & 1 & 1 \\
\hline Hardie et al., 2007 & LE & wetland & 0 & 0 \\
\hline Hardie et al., 2007 & LE & forest & 0 & 0 \\
\hline Hardie et al., 2007 & LE & agriculture & 0 & 0 \\
\hline Irwin and Bockstael, 2001 & AJAE & open space & 1 & 0 \\
\hline Irwin and Bockstael, 2001 & AJAE & preserve & 1 & 1 \\
\hline Irwin, 2002 & LE & agriculture & 0 & 0 \\
\hline Irwin, 2002 & $\mathrm{LE}$ & forest & 0 & 0 \\
\hline Irwin, 2002 & LE & preserve & 1 & 0 \\
\hline Irwin, 2002 & $\mathrm{LE}$ & open space & 1 & 0 \\
\hline Johnston et al., 2001 & GC & agriculture & 0 & 0 \\
\hline Johnston et al., 2001 & GC & open space & 0 & 0 \\
\hline Johnston et al., 2001 & $\mathrm{GC}$ & wetland & 0 & 0 \\
\hline Kim and Johnson, 2002 & SNR & forest & 0 & 0 \\
\hline Kuminoff, 2009 & JARE & agriculture & 1 & 0 \\
\hline Lee and Linneman, 1998 & REE & open space & 0 & 0 \\
\hline Legget and Bockstael, 2000 & JEEM & open space & 0 & 0 \\
\hline
\end{tabular}


(continued on next page)

(Appendix B, continued)

\begin{tabular}{|c|c|c|c|c|}
\hline Author(s) & Journal & Amenity $^{\mathrm{a}}$ & $\begin{array}{l}\text { Significant } \\
\text { and positive } \\
\text { effect }^{\text {b }}\end{array}$ & $\begin{array}{l}\text { Robust } \\
\text { effect }^{\text {b }}\end{array}$ \\
\hline Luttik, 2000 & LUP & open space & 0 & 0 \\
\hline Luttik, 2000 & LUP & forest & 1 & 1 \\
\hline Luttik, 2000 & LUP & diversity & 1 & 1 \\
\hline Lutzenhiser and Netusil, 2001 & CEP & preserve & 1 & 0 \\
\hline Mahan et al., 2000 & LE & wetland & 1 & 1 \\
\hline Mansfield et al., 2005 & JFE & forest & 1 & 0 \\
\hline Munroe, 2007 & EPB & open space & 0 & 0 \\
\hline Nelson, 1986 & JAPA & open space & 1 & 1 \\
\hline Nelson, 1986 & JAPA & open space & 0 & 0 \\
\hline Netusil, 2005 & LE & open space & 1 & 1 \\
\hline Netusil, 2005 & LE & forest & 1 & 0 \\
\hline Netusil, 2005 & LE & wetland & 0 & 0 \\
\hline Netusil, 2005 & $\mathrm{LE}$ & preserve & 0 & 0 \\
\hline Neumann et al., 2009 & LUP & diversity & 1 & 0 \\
\hline Neumann et al., 2009 & LUP & agriculture & 0 & 0 \\
\hline Neumann et al., 2009 & LUP & preserve & 1 & 0 \\
\hline Nicholls and Crompton, 2005 & JLR & open space & 0 & 0 \\
\hline Nicholls and Crompton, 2005 & JLR & open space & 0 & 0 \\
\hline Nicholls and Crompton, 2005 & JLR & open space & 0 & 0 \\
\hline Paterson and Boyle, 2002 & $\mathrm{LE}$ & agriculture & 0 & 0 \\
\hline Paterson and Boyle, 2002 & LE & forest & 0 & 0 \\
\hline Poudyal et al., 2009 & FPE & forest & 1 & 1 \\
\hline Poudyal et al., 2009 & FPE & diversity & 1 & 1 \\
\hline Ready and Abdalla, 2005 & AJAE & open space & 1 & 0 \\
\hline Ready and Abdalla, 2005 & AJAE & agriculture & 0 & 0 \\
\hline Sander and Polasky, 2009 & LUP & forest & 0 & 0 \\
\hline Sander and Polasky, 2009 & LUP & open space & 1 & 1 \\
\hline Shultz and King, 2001 & JREFE & preserve & 1 & 0 \\
\hline Shultz and King, 2001 & JREFE & open space & 0 & 0 \\
\hline Smith et al., 2002 & REE & open space & 0 & 0 \\
\hline Smith et al., 2002 & REE & forest & 0 & 0 \\
\hline Smith et al., 2002 & REE & agriculture & 0 & 0 \\
\hline Tapsuwan et al., 2009 & AJARE & wetland & 1 & 0 \\
\hline Thorsnes, 2002 & LE & forest & 1 & 0 \\
\hline Thorsnes, 2002 & $\mathrm{LE}$ & forest & 1 & 0 \\
\hline Thorsnes, 2002 & LE & forest & 0 & 0 \\
\hline Tyrväinen, 1997 & LUP & forest & 0 & 0 \\
\hline Tyrväinen and Miettinen, 2000 & JEEM, & forest & 1 & 1 \\
\hline White and Leefers, 2007 & SNR & forest & 0 & 0 \\
\hline White and Leefers, 2007 & SNR & open space & 0 & 0 \\
\hline
\end{tabular}

${ }^{\mathrm{a}}$ For definitions see section 5.1.

${ }^{\mathrm{b}}$ For definitions see section 5.2. 